\title{
Experimental Investigation of UHPFRC Cube and Cylinder Compression Test at Elevated Temperature
}

\author{
N. M. Sudarshan ${ }^{1 *}$, T. Chandrasekhar Rao ${ }^{2}$ \\ ${ }^{1}$ Department of Civil Engineering, Satara College of Engineering \& Management, Satara, India \\ ${ }^{2}$ Department of Civil Engineering, BEC, Bapatla, India \\ Email: ${ }^{*}$ msudarshan123@gmail.com
}

How to cite this paper: Sudarshan, N.M. and Chandrasekhar Rao, T. (2017) Experimental Investigation of UHPFRC Cube and Cylinder Compression Test at Elevated Temperature. Open Journal of Civil Engineering, 7, 282-296.

https://doi.org/10.4236/ojce.2017.72018

Received: January 20, 2017

Accepted: June 23, 2017

Published: June 26, 2017

Copyright $\odot 2017$ by authors and Scientific Research Publishing Inc. This work is licensed under the Creative Commons Attribution International License (CC BY 4.0). http://creativecommons.org/licenses/by/4.0/

\begin{abstract}
The present paper focuses on compressive strength of Ultra High Performance Fiber Reinforced Concrete (UHPFRC) cube and cylinder under compression testing machine, the experimental determination of test results shows $+5 \%$ variation in compressive strength, differs from normal concrete $+20 \%$ the ascending in strength development at an increased age under an elevated temperature of the material is identified with addition of hooked end steel fiber. In this study, the optimized mix design developed and the conversion ratios determined to develop relationship between cube and cylinder. The comparison between mean compressive strength ratio for cube and cylinder has been presented to determine high compressive strength. The research work is carried out to achieve enhanced target compressive strength $180 \mathrm{~N} / \mathrm{mm}^{2}$.
\end{abstract}

\section{Keywords}

UHPFRC, Steel Fiber, Micro Silica Quartz Sand, Super Plasticizer

\section{Introduction}

The UHPFRC is cement based composite material. The steel fibers are added to decrease the brittleness and increase compressive strength, the energy absorption capacity of the material increased by use of densified materials and special treatment, such as heat curing, pressure and extensive vibration, the structural geometry of hooked end steel fibers optimizing the matrix fiber interface properties and enhance the more compressive strength. Generally there are two types of test methods the cube and cylinder compression tests. In general cube compressive test is very common in Asian countries and cylinder test method in European countries in practice. The conventional concrete compressive strength of 
cube specimen is $20 \%$ higher than the cylindrical one. In UHPFRC the existence of steel fiber and exposure to temperature enhances the strength variation in $\pm 5 \%$ in cube and cylinder ratio. During the past 30 years the use of steel fiber reinforcement in concrete has taken places a considerable development to achieve higher compressive strengths to carry heavier loads throughout the life of the structure, suitable for adverse environmental conditions, aesthetic requirements and architectural appearance is most required in construction sector. Structural safety and suitability of the structure is the global challenge in present day and increased continuous terrorist attack, with bullet impact velocity $800 \mathrm{~m} / \mathrm{sec}$, earthquake tremor on rector scale 9.0 and Tsunami wind velocity $240 \mathrm{~km} / \mathrm{hr}$ to resist impacts a very high compressive strength, energy absorption capacity of concrete is necessary to minimize the loss of human life, valuable assets and structural failure. The researcher Yudenfreund et al. (1972) [1] investigated the high strength cement pastes with low w/c ratio ranges $(0.20$ - 0.30) and low porosity yielded high compressive strengths. Williamson (1974) [2] reported marginal change in compressive strength by use of steel fibers. Birchali et al. (1981) [3] achieved higher compressive strength of cement pastes, exceeding $200 \mathrm{Mpa}$ by special material preparation. Fanella and Naaman (1985) [4] showed increased stress strain curve by addition of steel fibers in concrete in compression increased strain rate at peak stress, energy absorbing capacity and increment in toughness. Bache (1987) [5] developed a densified small particles (DSP) concept for densely compacted granular matrix approach by use of silica fume and super plasticizer based on the water solubility theory of polymers and fine particles mainly consists of silica to improve rheological properties of cement mixture with low water cement ratio. D. M. Roy (1992) [6] introduced Chemically Bonded Ceramics $(\mathrm{CBC})$ a new class of cement based materials the chemical nature of the involvement of bond structure sub divided into two categories like DSP and MDF. Richard and Cheyrezy (1995) developed RPC (Refractive product concrete) enhancing compressive strengths by optimizing the granular particle mixture of cementitious Material PPD (Particle packing density). Collerpardi et al. (1998) [7] compared the RPC with the modified RPC and obtained the better results in strength, low porosity permeability and shrinkage, under steam curing, Jianxin Ma and Jorg Dietz (2002) [8] investigated the several properties of UHPC (Ultra high performance concrete) on work ability flow tests with percentage of admixture dosage to self compacting concrete and optimum $2 \%$ of powder mass to reduce air content for workable concrete. Resplendino. J. (2004) [9] observed UHPC with post peak stress response depends on alignment of fibers mixing placing, and compacting methodology the closer fiber accumulation at particular part due to gravitational orientation of steel fibers effect the compressive and tensile strength. Habel K. Denarie and Bruhwiler (2006) [10] adopted the probable possibilities usage of UHPFRC in rehabilitation of structural members time dependent based on the durability and proposed a numerical model and compared with the conventional concrete. Benjamin Graybeal and marshall Davis (2008) [11] investigated the UHPFRC alternative methods to compute compressive strengths of cube and cylinder ranging $100-200 \mathrm{~N} / \mathrm{mm}^{2}$ and dura- 
bility properties. Shihada S. and Arafa A. (2010) [12] studied the material properties in Gaza strip with addition of special materials, silica fume, quartz powder uniform mixing methodology to increase the dry density of UHPFRC optimum use of silica fume up to 15\% mass of cement. Yang, Joh, and Kim (2011) [13] investigated in UHPFRC beams use of steel fibers $2 \%$ with replacement of coarse aggregates the behavior of compressive, flexural failure deflection and initial cracking pattern measured. Barris et al. (2012) [14] studied performance of the concrete on different steel fibers based on orientation, content, material type and length. Ghafari E. et al. (2015) [15] based on statically mixture design (SMD) reported that the compressive strength is increased with higher dosage of micro silica by $1 \%-5 \%$ by weight of cement. The mix design shows enormous improvements in material properties. Rong et al. (2015) [16] observed that addition of nanosilica reduces the corrosion rate of steel. and reduction in capillary porosity the improved mechanical properties shows $0 \%-15 \%$ in compressive strength, $0 \%-2 \%$ in flexural strength and $0 \%-2.5 \%$ in splitting tensile strength, forming a denser, hardened cement material to carry heavier loads. Yuliarti Kusumawardaningsiha et al. [17] studied the compressive strength of UHPC and UHPFRC using cylinder and cube specimens and to determine its converting factors (ratio). The results show that the compressive strength relationships between specimens differ from those of conventional concrete. Hemraj R. Kumavat, Vikram J. Patel [18] experimental work carried out to investigate addition different size of aggregate and $\mathrm{w} / \mathrm{c}$ ratio on the mechanical properties standard size of cube and cylinder. R. Yu. P Spiesz H.J.H. Brouwers (2014) [19] developed densely compacted concrete mix design based on Andersen and Andersen packing model with addition of steel fiber $1 \%$ - $2 \%$ by volume of concrete Kazemi and Lubell (2012) [20] observed that cube specimens exhibited higher compressive strength compared with cylinder specimens $\mathrm{H}$. M. Al-Hassani et al. (2014) [21] indicated increasing the volume fraction of steel fibers from $0 \%$ to $1.0 \%, 2.0 \%$, and $3.0 \%$ the cube compressive strength was increased by $3.72 \%$, $8.36 \%$, and $8.89 \%$ respectively, while the cylinder compressive strength was increased by $6.36 \%, 9.9 \%$, and $11.54 \%$ respectively by Sudarshan N. M. and T. Chandrashekar Rao (2015) [22].

From the literature survey it is clear that many researchers has done work only on variation in composition for the mix design. The high Compressive strength determination and development a great challenge in limited testing capability and availability of surface area preparation. The conversion factor is prime important to determine accurate compressive strength of the concrete in relationship with cube and cylinder to improve performance of the structure, safety and stability point of view. The Maintenance cost can be reduced. Here in this research work optimized the mix design developed for water binder ratio $(\mathrm{w} / \mathrm{b}=0.18)$ and cube, cylinder compressive tests conducted and compressive strengths determined for various days and In comparison of compressive strengths and mean conversion ratios ranges $0.98-1.05$ for cube and cylinder in relationship to determine accurate compressive strength presented. The time and testing cost saving is beneficial in construction sector. 


\section{UHPFRC Material Properties}

\subsection{Cement}

The Ultra-tech Portland cement of 53 Grade conforming to IS-12269 2013, particle size $1-100 \mu \mathrm{m}$ normal consistency of $28 \%$ with specific gravity of 3:15 used. The physical and chemical properties as per standards in Table 1 and Table 2.

\subsection{Micro Silica}

The Elkemmicro Silica conforming to Grade 920-D with a grain size 0.2 microns, non combustible irregular shape fine particles and surface area $\left(B E T \mathrm{M}^{2}\right.$-gm < 15) specific gravity 2.25 was used as mineral admixture. The properties and standards in Table 3.

\subsection{Sand}

The locally available natural river sand free from impurities with less than $1 \mathrm{~mm}$ size sieved through, 1000 microns sieve analysis done as per IS 2386-1963 having specific gravity 2.63 conforming to IS 650 specifications. Particle size distribution as shown in Figure 1.

\subsection{Quartz}

The quartz sand was used from locally available source sized 150 - 1000 microns contained $99 \%$ silicon dioxide; the specific gravity of quartz sand is 2.59 .

\subsection{Steel Fibers}

The Dura flex bright hard non glued, hook end steel fibers of dia. $0.6 \mathrm{~mm}$ and length $30 \mathrm{~mm}$ with modulus of elasticity $210 \mathrm{GPa}$ tensile strength more than

Table 1. Physical requirement.

\begin{tabular}{ccc}
\hline Characteristic & Requirement & Method of Test \\
\hline Finess $\mathrm{m}^{2} / \mathrm{kg}$ min & 225 & IS 4031 Part (2) \\
Soundness & $10-80$ & IS 4031 Part (3) \\
Setting time Initial & $60 \mathrm{~min}$ & IS 4031 Part (5) \\
Final & $600 \mathrm{~min}$ & --------- \\
Transverse Strength & $72 \mathrm{hrs}$. & IS 4031 Part (8) \\
Compressive strength & $53 \mathrm{MPa}$ & IS 4031 Part (6)
\end{tabular}

Table 2. Chemical requirements.

\begin{tabular}{cc}
\hline Characteristic & Requirement \\
\hline Ratio of percentage of lime to silica, alumina & 0.90 \\
Ratio of percentage of alumina to iron oxide & 0.66 \\
Magnesia percent by mass max. & 6.00 \\
Chloride content by mass & 0.10 \\
Loss of ignition & 4.00 \\
\hline
\end{tabular}


$1000 \mathrm{MPa}$ having aspect ratio $(\mathrm{a} / \mathrm{r})=50$ The fiber properties and dimension in Table 4 are used.

\subsection{Super Plasticizer}

The addition of polymer based Sulphonated naphthalene conplast SP430 DIS admixture used to increases the liquid quantity and adequate workability of concrete to provide excellent acceleration of strength gain reducing water demand in a rheological behavior of concrete mix and its specific gravity is 1.00 confirms to ASTM-C494 type-F.

\subsection{Water}

The pure, drinkable water free from chemical, mineral impurities used for mixing \& curing to improve the quality and strength of the material clean potable

Table 3. Physical and chemical requirements.

\begin{tabular}{ccc}
\hline properties & unit & Specification \\
\hline $\mathrm{SIO}_{2}$ & $\%$ & $>85$ \\
Moisture & $\%$ & $<3.0$ \\
Loss of Ignition LOI & $\%$ & $<6.0$ \\
Specific surface BET & $\mathrm{M}^{2} / \mathrm{gm}$ & $>15$ \\
Pozz. Activity Index & $\%$ & $>105$ \\
Retained 45 mi sieve & $\%$ & $<10$ \\
Bulk Density & $\mathrm{Kg} / \mathrm{m}^{3}$ & $500-700$
\end{tabular}

Table 4. Physical properties.

\begin{tabular}{cc}
\hline Description & Dimension \\
\hline Shape & Bright, Clear and hard \\
Standard & As per ASTM A820 M \\
& EN10088, EN10016-4 \\
Young Modulus & $210 \mathrm{~N} / \mathrm{mm}^{2}$ \\
Tolerances & $\pm 5 \%$ to $8 \%$ \\
Aspect Ratio & 50 \\
Form & Hook anchorage Loose (Non glued) \\
\hline
\end{tabular}

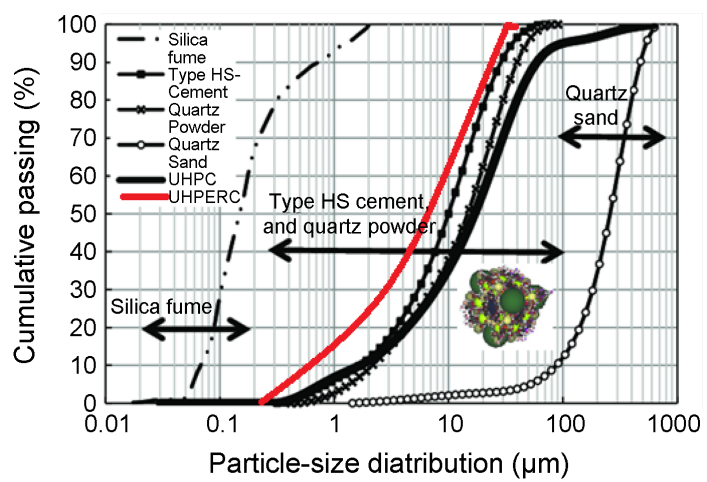

Figure 1. Grain size particle distribution $(\mu \mathrm{m})$. 
water plays a vital role with super plasticizer to gain higher strengths. The typical range of materials shown in Table 5.

\section{Mixture Proportions}

The mixture proportions optimisation for the granular mix, designed by various researchers to achieve higher compressive strengths as shown in Table 6.

\subsection{Binders}

A Binder is a mixture of high proportion of cement and silica fume used various mixtures by Rossi et al. $2008\left(1318 \mathrm{Kg} / \mathrm{m}^{3}\right)$, Magureanu et al. 2010 (754 $\left.\mathrm{Kg} / \mathrm{m}^{3}\right)$, Katrin Habel et al. $2005\left(1325 \mathrm{~kg} / \mathrm{m}^{3}\right)$, Eshan Ghafari et al. $2015(1387$ $\left.\mathrm{kg} / \mathrm{m}^{3}\right)$, Hamdy K. Shehab Eldin et al. $2014\left(935 \mathrm{Kg} / \mathrm{m}^{3}\right)$, Prabhat Ranjan Prem et al. $2012\left(985 \mathrm{Kg} / \mathrm{m}^{3}\right)$, Alaa ABashandy $2013\left(1042 \mathrm{Kg} / \mathrm{m}^{2}\right)$ [23]-[29] to develop high compressive strength. In the present research work to improve workability and filling voids a suitable binder proportion of $1210 \mathrm{~kg} / \mathrm{m}^{3}$ used.

\subsection{Water/Binder Ratio}

Avery low water binder ratio is used for achieving better results Rossi et al. 2004 (0.11) high percentage hooked end steel fibers $25 \mathrm{~mm}$ in length and $0.3 \mathrm{~mm}$

Table 5. Typical range of UHPFRC constituents in $\mathrm{Kg} / \mathrm{m}^{3}$.

\begin{tabular}{cccc}
\hline Components & Min. & Max. & \% by wt. \\
\hline Cement & 800 & 1500 & $1.00-2.00$ \\
Fine Sand & 1000 & 1800 & $1.25-2.25$ \\
Micro silica & 125 & 275 & $0.18-0.37$ \\
Quartz & 180 & 350 & $0.22-0.43$ \\
Steel fiber & 118 & 390 & $0.09-0.29$ \\
Super plasticizer & 15 & 60 & $0.01-0.07$ \\
Water & 120 & 200 & $0.15-0.25$ \\
\hline
\end{tabular}

Table 6. UHPFRC mixture components by mass of cement.

\begin{tabular}{|c|c|c|c|c|c|c|}
\hline Components & $\begin{array}{c}\text { Current } \\
\text { study }\end{array}$ & $\begin{array}{l}\text { Magureanu } \\
\text { C. et al. [24] }\end{array}$ & $\begin{array}{c}\text { Richard \& } \\
\text { cheyrezy [30] }\end{array}$ & $\begin{array}{c}\text { Delarad \& } \\
\text { Sedran [31] }\end{array}$ & $\begin{array}{c}\text { Prabhat } \\
\text { Ranjan P. [28] }\end{array}$ & $\begin{array}{c}\text { Alaa A } \\
\text { Bashandy [29] }\end{array}$ \\
\hline Cement & 1.00 & 1.00 & 1.00 & 1.00 & 1.00 & 1.00 \\
\hline Quartz sand & 0.30 & -- & 0.39 & -- & 0.39 & -- \\
\hline Silica fume & 0.25 & 0.26 & 0.23 & 0.31 & 0.25 & 0.30 \\
\hline Steel fibers & 0.21 & 0.17 & -- & -- & 0.24 & 0.05 \\
\hline $\begin{array}{c}\text { Super } \\
\text { plasticizer (\%) }\end{array}$ & 3.5 & 3.0 & 2.3 & 1.3 & 2.10 & 10.00 \\
\hline Fine aggregate & 1.32 & 1.18 & 1.10 & 0.75 & 1.1 & 1.78 \\
\hline water/binder & 0.18 & 0.14 & 0.13 & 0.14 & 0.17 & 0.18 \\
\hline $\begin{array}{l}\text { Compressive } \\
\text { strength } \mathrm{MPa}\end{array}$ & 168 & 167 & 145 & 165 & 162 & 210 \\
\hline
\end{tabular}


in diameter. Katrin Habel et al. 2005 (0.14), incorporated high percentage of straight steel fibers $10 \mathrm{~mm}$ in length and $0.2 \mathrm{~mm}$ in diameter. Shan Ghafari et al. 2015 (0.17) minimum content of hybrid steel fibers, Hamdy K. shehab Eldin et al. 2014 (0.13) addition straight steel fibers $50 \mathrm{~mm}$ in length and $1.0 \mathrm{~mm}$ in diameter, Prabhat ranjanprem et al. 2012 (0.17) chosen straight steel fibers $6 \mathrm{~mm}$ in length and $0.16 \mathrm{~mm}$ in diameter. Alaa A Bashandy 2013 (0.18) [23]-[29] steel fiber enhance the behavior of compressive strength with increased cement and super plasticizer $(10 \%)$ percentage the water binder $(\mathrm{w} / \mathrm{b})$ ratio is very important parameter in increased compressive strength gaining. at elevated temperature. The various researchers UHPFRC mixture proportions shown in Figure 6. In this research work taking into consideration micro filler effect the water binder ratio maintained 0.18 with non glued hooked end steel fibers having aspect ratio 50 used to achieve highest compressive strength of the concrete.

\subsection{Mix Design}

A UHPFRC mix design material constituents are Cement, Fine sand, Micro silica, quartz sand, super plasticizer, with low water cement ratio with addition of 2.0\% Hooked end steel fiber to resist crack expansion. The UHPFRC Composite is designed for $\geq 160 \mathrm{~N} / \mathrm{mm}^{2}$.

\section{1) Packing Density}

The factors responsible for reduction of porosity and obtaining maximum packing density for conventional concrete studied by Fuller and Thomson [32] expressed by cumulative grain size distribution equation

$$
y(i)=\frac{D_{i}^{n}}{D_{\max }^{n}} 100 \%
$$

where $y(i)$-cumulative $\%$ of $i^{\text {th }}$ fraction, $D_{i}$-Diameter of the $i^{\text {th }}$ fraction in $(\mathrm{mm}), D_{\max }$-Diameter of Max grain size $(\mathrm{mm}) n-$ a constant value equal to 0.5 .

Based on the research work Funk [33] adopted the Fullers curve for composite material similar to UHPFRC

$$
y(i)=\left[\frac{D_{i}^{n}-D_{\min }^{n}}{D_{\max }^{n}-D_{\min }^{n}}\right] 100 \%
$$

$y(i)$-cumulative $\%$ of $i^{\text {th }}$ fraction, $D_{i}$-Diameter of the $i^{\text {th }}$ fraction in $(\mathrm{mm})$, $D_{\max }$-Diameter of Max grain size $(\mu \mathrm{m}) n-$ a constant value equal to 0.37 . The detailed steps involved mixture design is shown in Flow diagram Figure 2.

\section{2) The Mixing operation involves the following steps}

i) The Dry cement, fine sand, micro silica and quartz powder per $\mathrm{m}^{3}$ put in a mixer machine as per the design proportions and mix is provided with a uniform blending, so as to form a homogeneous material.

ii) For a well mixed homogeneous mixture potable water is added until the materials have coagulated.

iii) Wait for few minutes to confirm the water is reacted properly to form a cement paste mixing was continued at low speed. 
iv) Addition of super plasticizer to the coagulated mixture.

v) Hooked end steel fibers by spreading on the cement paste and mix it thoroughly to get consistent material. The stepwise preparation of UHPFRC materials shown in Figure 3 and blended mix material in Figure 4.

\subsection{Casting}

A three series of specimens cube are casted of sizes $150 \times 150 \times 150 \mathrm{~mm}$ and

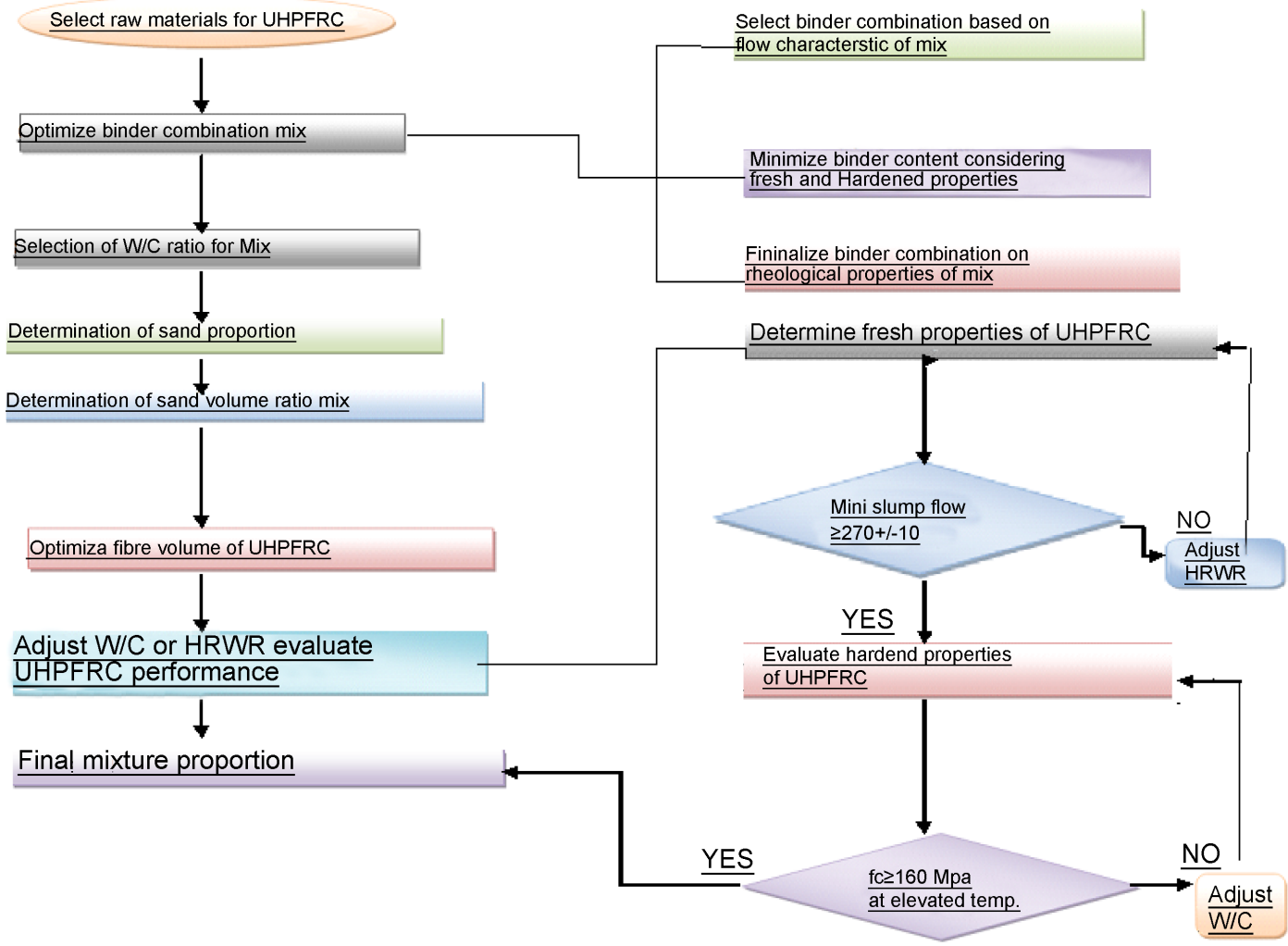

Figure 2. Flow diagram of mix design.

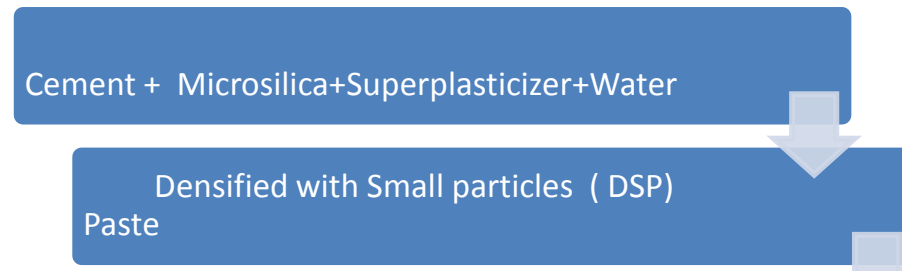

\section{+Fine Aggregate + Steel Fibre}

\section{Macro Defect Free (MDF) Mixture}

Ultra High Performance Fibre Reinforced

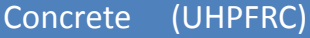

Figure 3. Typical UHPFRC preparation. 
cylinder $150 \mathrm{~mm}$ dia. $300 \mathrm{~mm}$ height with uniform vibrating the top surface were given with smooth finishing, the specimens demoulded after 24 hours. Casted specimens as shown in Figure 5.

\subsection{Curing}

The curing regime of specimens includes exposing the specimens to thermal treatment to enhance material properties at a temperature of $90^{\circ} \mathrm{C}$ for duration

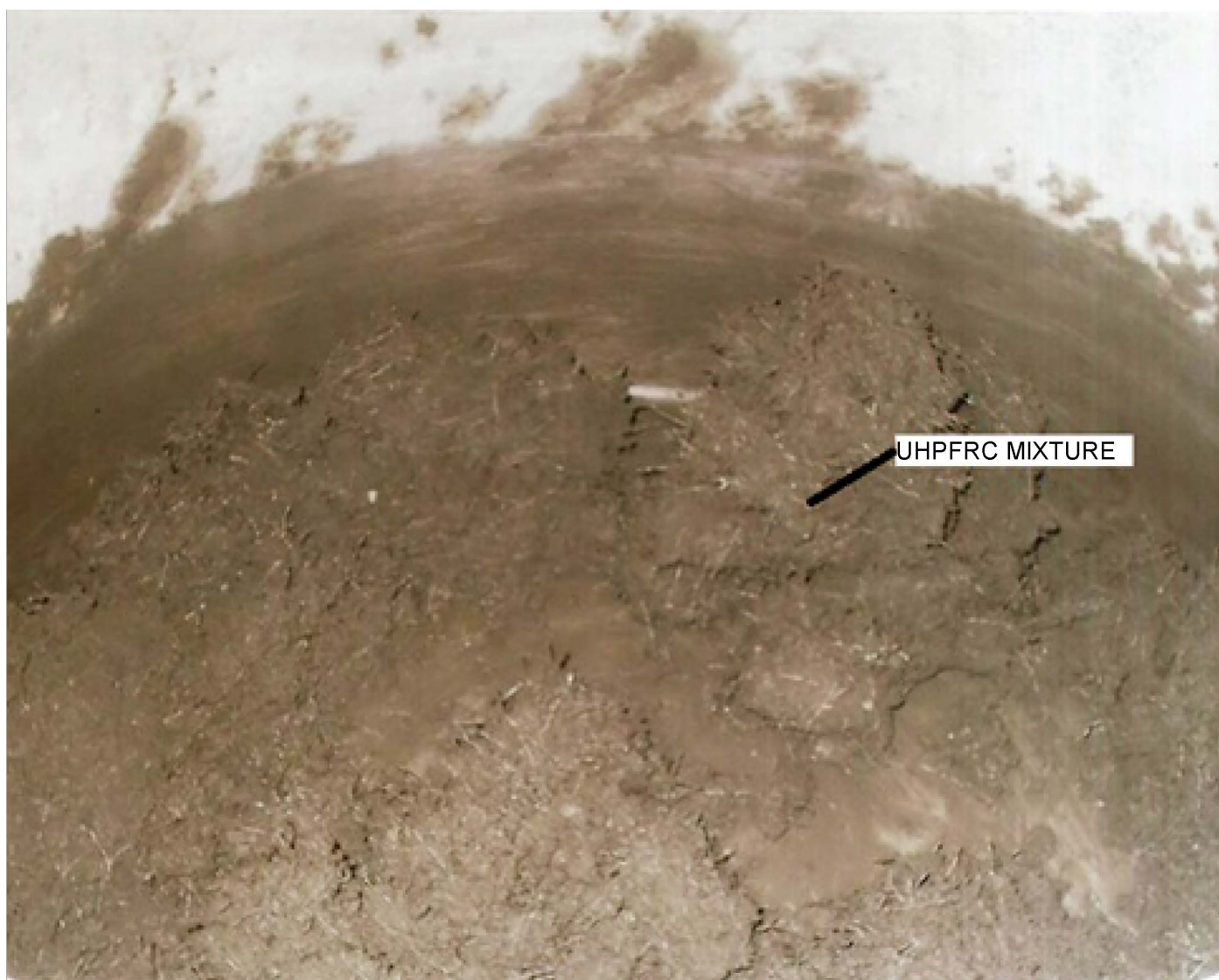

Figure 4. UHPFRC blended mix.

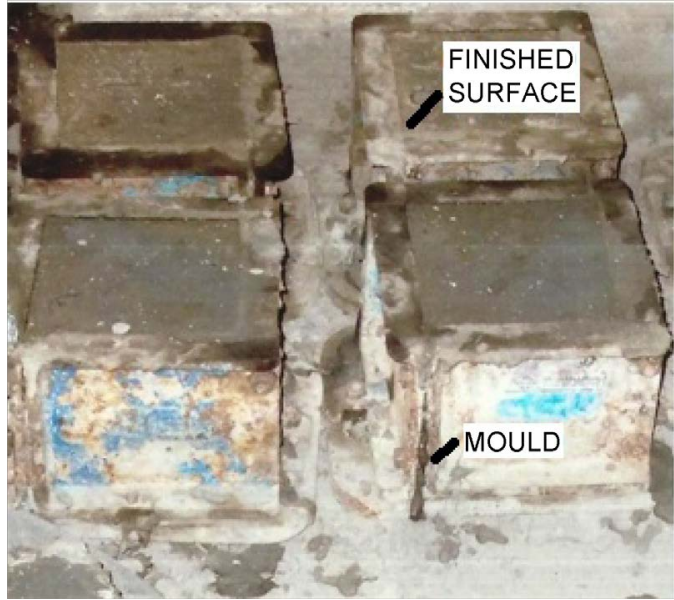

Figure 5. Casted cube specimens. 
of 24 hours the specimens are removed from the thermostat cabin and allowed to cool for about 3 hours.

\subsection{Testing}

\section{Compressive test}

In testing program compressive test on cube specimen size $150 \times 150 \times 150 \mathrm{~mm}$, and $150 \mathrm{~mm}$ dia. Height $300 \mathrm{~mm}$ cylinder for 3, 7, 14, 28, days conducted as per ASTM C 39 standards on computer-controlled electromechanical servo hydraulic pressure Compression testing machine $3000 \mathrm{KN}$ Figure 6 with standard procedures compression testing machine applied load at the rate $5 \mathrm{KN} / \mathrm{sec}$, the ultimate load on the specimen recorded. The compressive strength is determined using Equation (1) A typical failure pattern is by crushing is shown in Figure 7 cube and Figure 8 cylinder

$$
F_{c}=\frac{P}{A}
$$

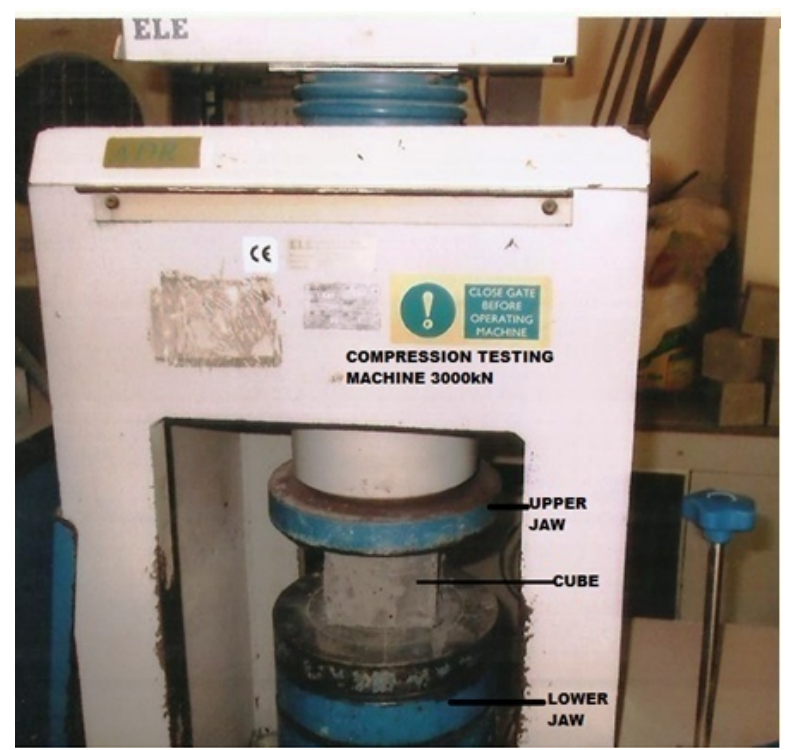

Figure 6. Automatic compression testing machine $3000 \mathrm{KN}$.

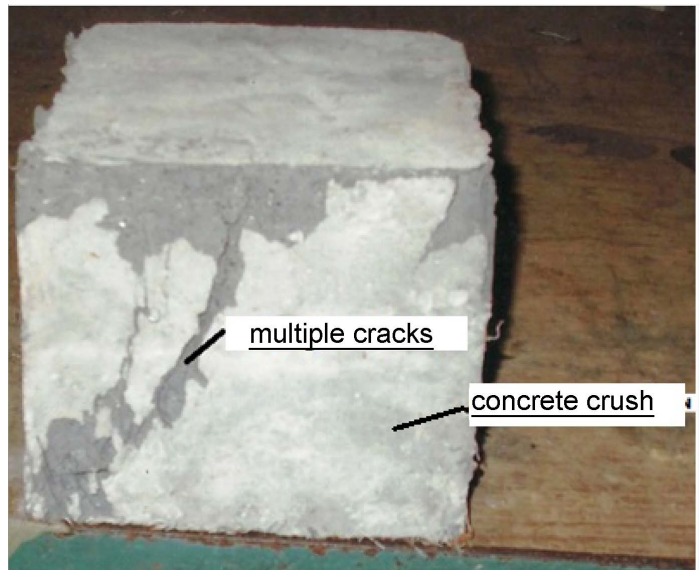

Figure 7. Fracture cube specimen. 
$F_{c}=$ Compressive strength, $P=$ Load, $A=$ Cross sectional area.

The compressive strength of cube and cylinder fluctuates around $165 \mathrm{~N} / \mathrm{mm}^{2}$ and $160 \mathrm{~N} / \mathrm{mm}^{2}$ the difference between obtained compressive strength of cube and cylinder is relatively very small and the mean compressive strength, and

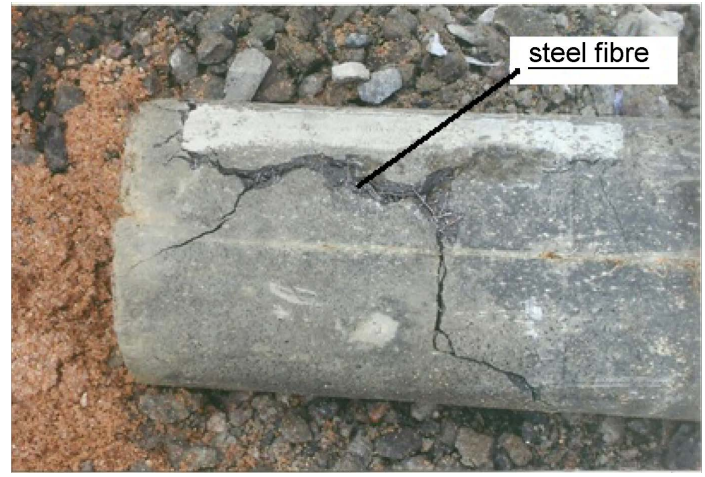

Figure 8. Fracture cylinder specimen.

Table 7. Experimental results for cube and cylinder.

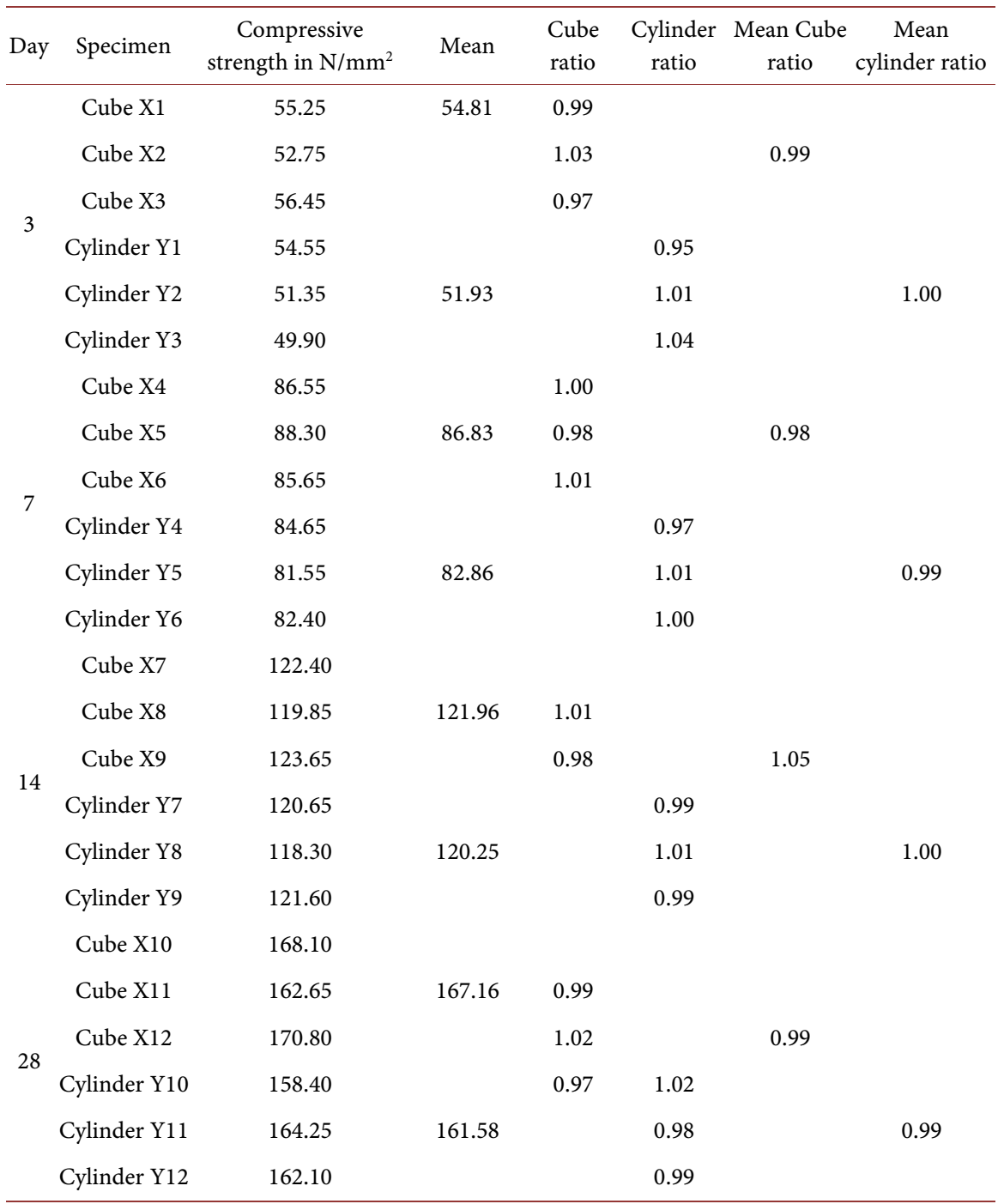


cube, cylinder ratio tabulated in Table 7. From the experimental test results it shows the compressive strength is higher than Normal strength concrete (NSC), High strength concrete (HSC), Sudarshan N M and T Chandrashekar Rao [34]. The introduction of vibration during casting, mixing stage effects on the compressive strength and durability of concrete The addition of steel fibers results highest compressive strength and restricted in crack development and strain hardening capacity of the material.

\section{Results and Discussions}

The experimental test results shows compressive strength of cube is higher than the cylinder, due to the increased cube surface area $150 \times 150 \mathrm{~mm}$ and that of cylinder $150 \mathrm{~mm}$ diameter, the absence of coarse aggregate less than $1 \mathrm{~mm}$ size fine aggregates use and hooked end steel fibers increase densely compactness and ductility of the matrix material atelevated temperature. In the present experimental conversion ratio of $\left(f_{\mathrm{cu}} / f_{\mathrm{cy}}\right)$ cube compressive strength to at 28 day ranges between $\left(0.95\right.$ - 1.04). The mean compressive strengths of $168.16 \mathrm{~N} / \mathrm{mm}^{2}$ for cube specimen and $161.58 \mathrm{~N} / \mathrm{mm}^{2}$ for cylinder $2 \%$ steel fibers. The mean compressive strength V/S mean ratio of cube and cylinder shown in Figure 9 and a comparison of mean compressive strength V/S Day shown in Figure 10 the higher compressive strength is obtained due to optimized granular mixture, silica fume pozzolanic reaction, compacted density and exposure to elevated temperature. It can be observed that the mean compressive strength conversion ratios of 3 series of between cube and cylinder namely (0.99) this ratio is ranges of UHPFRC is close to the conversion factors and by AMPA (2010) [35] which is 0.95 and by the Torsten Leutbecher (2014) [36] which is 0.96 these conversion ratios necessary to consider barring factors influence occurred by specimens Mansur and Islam (2004) [37]. Investigated compressive strength on cylinder and cube of $100 \mathrm{~mm}$ and $150 \mathrm{~mm}$ dia. the results shown almost similar with

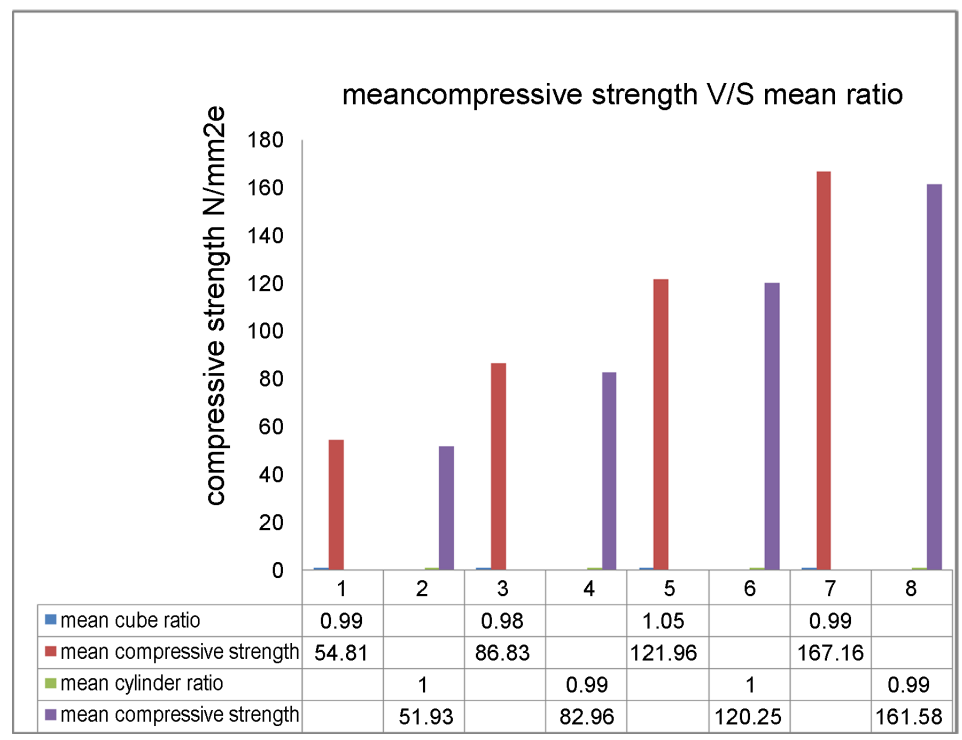

Figure 9. Mean compressive strength $\mathrm{V} / \mathrm{S}$ mean ratio. 


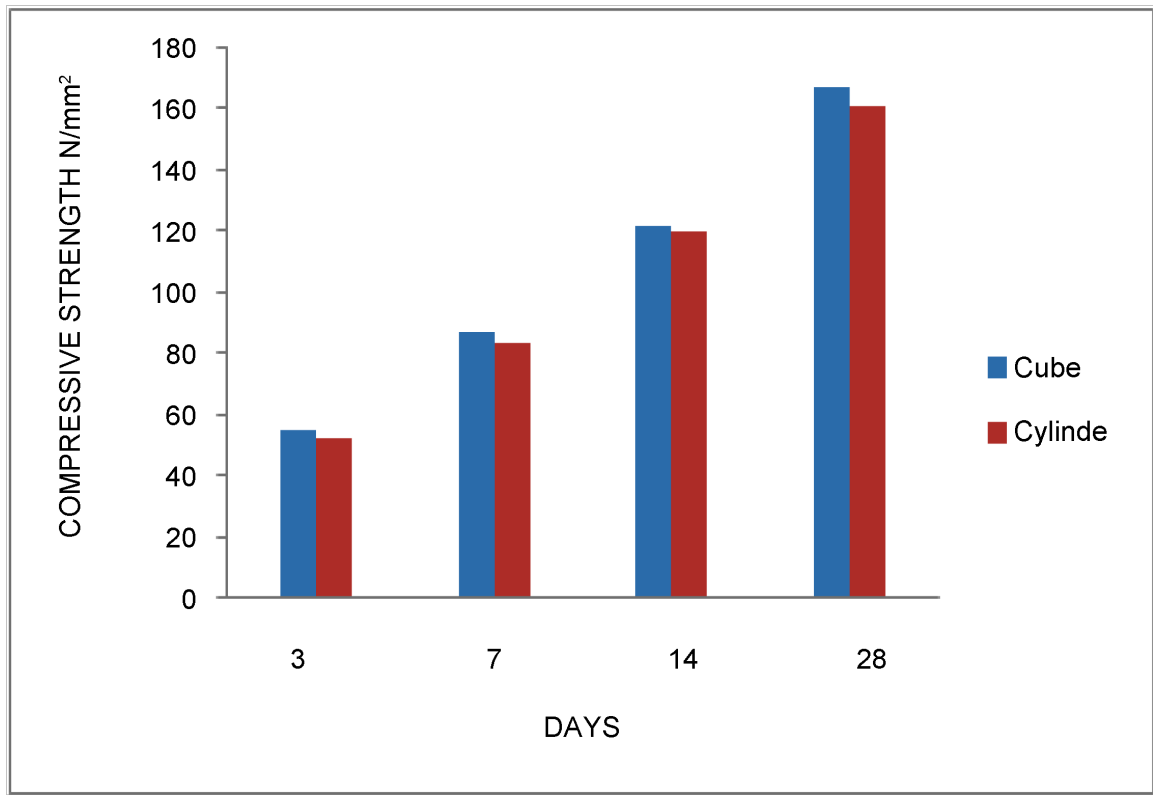

Figure 10. Mean compressive strength V/S Days.

marginal increase in the cube strength Benjamin A Grabeal and Marshall Davis (2008) [38] concluded cube and cylinder of 100 and $102 \mathrm{~mm}$ diameter results the cube strength is higher than the cylinder.

\section{Conclusion}

The sample of specimens tested for cube and cylinder resulted compressive strengths obtained less than the design strength $180 \mathrm{~N} / \mathrm{mm}^{2}$. It is noted that the compression strength of UHPFRC obtained using cube specimens is not precise uniaxial strength, thus converting its value to the cylinder specimen values is necessary. In order to determine the correct compression strength of UHPFRC, by considering barring factors occurred by the specimens the 0.99 conversion factor applied to cube strength equivalent cylinder strength in relationship, to determine accurate strength and development, the removal of coarse aggregates enhances homogeneity, steel fibers influence on mean strength ratio $1 \%-5 \%$ for UHPFRC and $10 \%-20 \%$ in normal concrete the difference decreases with increase in strength and failure occurs by rupture. The present studies conclude $5 \%$ increase in the cube strength higher than cylinder for UHPFRC mixture.

\section{References}

[1] Yudenfreund, M., Odler, I. and Brunauer, S. (1972) Hardened Portland Cement Pastes of Low Porosity I. Materials and Experimental Methods. Cement and Concrete Research, 2, 313-330. https://doi.org/10.1016/0008-8846(72)90073-7

[2] Ezeldin, A.S. and Balaguru, P.N. (1992) High-Strength Fiber-Reinforced Concrete under Compression. Journal of Material Engineering, 4, 415-429. https://doi.org/10.1061/(asce)0899-1561(1992)4:4(415)

[3] Birchali, J.D., Howard, A.J. and Kendall, K. (1981) Flexural Strength and Porosity of Cements. Nature, 289, 388-390.

[4] Fanella, D.A. and Naaman, A.E. (1985) Stress Strain Properties of Fiber Reinforced 
Mortar in Compression. ACI Journal, 82, 475-483.

[5] Bache, H. (1981) Densified Cements Ultra-Fine Particle-Based Materials. Proceedings of the 2 nd International Conference on Super Plasticizers in Concrete, Ottawa, Canada, $33 \mathrm{p}$.

[6] Roy, D.M. (1992) Advanced Cement System Including CBC, DSP, MDF. 9 th International Congress on the Chemistry of the Cement, New Delhi, India, 357-380.

[7] Collepardi, S., Coppola, L., Troli, R. and Collepardi, M. (1998) Mechanical Properties of Modified Reactive Powder Concrete. A Report Vo. 95, May-June 1998, 284-292.

[8] Ma, J.X., Dietz, J. and Dehn, F. (2002) Ultra High Performance Self Compacting Concrete. Lacer, 7, 33-42.

[9] Resplendino, J. (2004) First Recommendations for Ultra High-Performance Concretes and examples of application. Proceedings of the International Symposium on Ultra High Performance Concrete, Kassel, Germany, 13-15 September 2004, 79-91.

[10] Habel, K., Denarie, E. and Bruhwiler, E. (2006) Structural Response of Elements Combining Ultra high Performance Fiber Reinforced Concretes. Journal of Structural Engineering, 132, 1793-1800. https://doi.org/10.1061/(ASCE)0733-9445(2006)132:11(1793)

[11] Benjamin, A. (2006) Grabeal Material Property Characterization of Ultra-High Performance Concrete. Publication No. FHWA-HRT-2006 06-10.

[12] Shihada, M. and Arafa, S. (2006) Effects of Silica Fume, Ultrafine and Mixing Sequences on Properties of Ultra High Performance Concrete. Asian Journal of Materials Science, 23, 137-146.

[13] Yang, I.H., Joh, C. and Kim, B.S. (2011) Flexural Strength of Ultra High Strength Concrete Beams Reinforced with Steel Fibers. Procedia Engineering, 14, 793-796. https://doi.org/10.1016/j.proeng.2011.07.100

[14] Barris, C., Torres, L., Mias, C. and Vilanova, I. (2012) Design of FRP Reinforced Concrete Beams for Serviceability Requirements. Journal of Civil Engineering and Management, 18, 843-857. https://doi.org/10.3846/13923730.2012.720934

[15] Ghafari, E., Costa, H. and Júlio, E. (2015) Statistical Mixture Design Approach for Eco-Efficient UHPC. Cement and Concrete Composites, 55, 17-25.

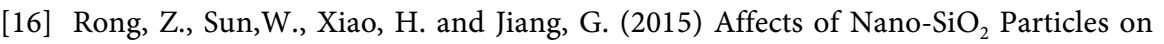
the Mechanical and Micro Structural Properties of Ultra High Performance Cementitious Composites. Cement and Concrete Composites, 56, 25-31.

[17] Kusumawardaningsih, Y., Fehling, E. and Ismail, M. (2015) UHPC Compressive Strength Test Specimens: Cylinder or Cube? Procedia Engineering, 125, 1076-1080.

[18] Kumavat, H.R. and Patel, V.J. (2014) Factors Influencing the Strength Relationship of Concrete Cube and Standard Cylinder. International Journal of Innovative Technology and Exploring Engineering (IJITEE), 3, 76-79.

[19] Yu, R., Spiesz, P. and Brouwers, H.J.H. (2014) Mix Design and Properties of Ultrahigh Performance Fiber Reinforced Concrete (UHPFRC). Cement and Concrete Research, 56, 29-39. https://doi.org/10.1016/j.cemconres.2013.11.002

[20] Kazemi, S. and Lubell, A. (2012) Influence of Specimen's Size and Fiber Content on Mechanical Properties of Ultra High Performance Fiber Reinforced Concrete. ACI Materials Journal, 109, 675-684.

[21] Al-Hassani, H.M., Khalil, W.I. and Danha, L.S. (2014) Mechanical Properties of Reactive Powder Concrete with Various Steel Fiber and Silica Fume Contents. Acta Tehnica Corviniensis-Bulletin of Engineering, Tome VII 1.

[22] Sudarshan, N.M. and Chandrasekhar Rao, T. (2015) Mechanical Properties Assessment of Ultra High Performance Fiber Reinforced Concrete (UHPFRC). International 
Journal for Research in Applied Science \& Engineering Technology, 3, 839-844.

[23] Rossi, P. and Parant, E. (2005) Durability of an Ultra-High Fibre Reinforced Cement Composite Under a Service State Loading and in an Aggressive Environment. Cement and Concrete Research, 377, 1106-1114.

[24] Magureanu, C., Sosa, I., Negrutiu, C. and Heghes, B. (2010) Physical and Mechanical Properties of Ultra-High Strength Fiber Reinforced Cementitious Composites. In: Oh, B.H., et al., Eds., Fracture Mechanics of Concrete and Concrete Structures, High Performance, Fiber Reinforced Concrete, Special Loadings and Structural Applications, Korea Concrete Institute, 1487-1491.

[25] Habel, K., et al. (2008) Ultra-High Performance Fiber Reinforced Concrete in Central Canada. Canadian Journal of Civil Engineering, 35, 217-224. https://doi.org/10.1139/L07-114

[26] Ghafari, E., Costa, H. and Julio, E. (2015) Statistical Mixture Design Approach for Eco-Efficient UHPC. Cement and Concrete Composite, 55, 17-25.

[27] Eldin, H.K.S., Mohamed, H.A., Khater, M. and Ahmed, S. (2014) Mechanical Properties of Ultra-High Performance Fiber Reinforced Concrete. International Journal of Engineering and Innovative Technology, 4, 4-10.

[28] Prem, P.R., Bharatkumar, B.H. and Iyer, N.R. (2012) Mechanical Properties of Ultra High Performance Concrete. World Academy of Science, Engineering and Technology IJCSAE, 6.

[29] Bashandy, A.A. (2013) Influence of Elevated Temperatures on the Behavior of Economical Reactive Powder Concrete. Journal of Civil Engineering Research, 3, 89-97.

[30] Richard, P. and Cheyrezy, M. (1995) Composition of Reactive Powder Concretes. Cement and Concrete Research, 25, 1501-1511. https://doi.org/10.1016/0008-8846(95)00144-2

[31] de Larrard, F. and Sedran, T. (2002) Mixture-Proportioning of High-Performance Concrete. Cement and Concrete Research, 32, 1699-1704. https://doi.org/10.1016/S0008-8846(02)00861-X

[32] Fuller, W. and Thomson, S. (1907) The Laws of Proportioning Concrete. Transactions of the American Society of Civil Engineers, LIX, 67-143.

[33] Funk, J. and Dinger, D. (1994) Predictive Process Control of Crowded Particulate Suspensions. Kluwer Publishers, London.

[34] Sudarshan, N.M. and Chandrashekar Rao, T. (2017) Vibration Impact on Fresh Concrete of Conventional and UHPFRC. International Journal of Applied Engineering Research, 12, 1683-1690.

[35] AMPA (Amtliche Material prufanstaltfurda) (2010) Bauwesen Druckfestigkeitfactor. Kassel Unversitaet, Kassel.

[36] Leutbecher, T. (2014) Material Properties of UHPC. Chapter 4, Kassel University.

[37] Mansur, M. and Islam, M. (2002) Interpretation of Concrete for Nonstandard Specimens. Journal of Materials in Civil Engineering, 14, 151-155. https://doi.org/10.1061/(ASCE)0899-1561(2002)14:2(151)

[38] Graybeal, B. and Davis, M. (2008) Cylinder or Cube: Strength Testing of 80 to 200 MPa (116 to29 ksi) Ultra-High Performance Fiber Reinforced Concrete. ACI Material Journal, 105, 603-609. 
Submit or recommend next manuscript to SCIRP and we will provide best service for you:

Accepting pre-submission inquiries through Email, Facebook, LinkedIn, Twitter, etc. A wide selection of journals (inclusive of 9 subjects, more than 200 journals)

Providing 24-hour high-quality service

User-friendly online submission system

Fair and swift peer-review system

Efficient typesetting and proofreading procedure

Display of the result of downloads and visits, as well as the number of cited articles Maximum dissemination of your research work

Submit your manuscript at: http://papersubmission.scirp.org/

Or contact ojce@scirp.org 